Acta Theriologica 40 (2): 113-121, 1995.

PL ISSN 0001-7051

\title{
Diet of Sorex coronatus in the western Pyrenees
}

\author{
Enrique CASTIÉN and Joaquim GOSÁLBEZ
}

\begin{abstract}
Castién E. and Gosálbez J. 1995. Diet of Sorex coronatus in the western Pyrenees. Acta Theriologica 40: 113-121.

The diet of Sorex coronatus (Millet, 1828) was studied by the analysis of digestive tracts from 178 individuals collected in Quinto Real Massif, western Pyrenees (north of the Iberian Peninsula). In total, 28 different types of food were determined. The most important prey species, as determined by numerical presence $(\mathrm{N})$ and Simpson's dominance index (D"), were Chilopoda $(\% \mathrm{~N}=12.8 ; \mathrm{D} "=21.4)$, Diptera larvae $(\% \mathrm{~N}=22.0$; $\mathrm{D}=17.7)$, Oligochaeta: Opistopora $\left(\% \mathrm{~N}=11.3 ; \mathrm{D}^{\prime \prime}=12.2\right)$, Gastropoda $(\% \mathrm{~N}=7.0 ; \mathrm{D}=8.7)$, adult Coleoptera $(\% \mathrm{~N}=6.9 ; \mathrm{D} "=8.0)$ and Hemiptera $(\% \mathrm{~N}=6.0 ; \mathrm{D} "=5.3)$. Diets of both sexes were similar. The diet of $S$. coronatus in the study area was similar to the diet of $S$. araneus described in the literature.

Servicio de Medio Ambiente, Gobierno de Navarra, C./ Alhóndiga 1, 31002 Pamplona. Navarra, Spain (EC); Dept. de Biologia Animal, Fac. de Biologia, Univ. de Barcelona, Avgda. Diagonal 645, 08028 Barcelona, Spain (JC).

Key words: Sorex coronatus, diet, trophic ecology, Iberian Peninsula
\end{abstract}

\section{Introduction}

Since Sorex coronatus (Millet, 1828) was discovered as a sibling species of Sorex araneus (Meylan 1964, Meylan and Hausser 1978, Catzeflis et al. 1982, Hausser 1984, Hausser et al. 1985), research efforts have focused on discovering the ecological strategies of each species. Recently some information has appeared on habitat usage in parapatric contact areas (Handwerk 1987, Neet and Hausser 1990, Brünner and Neet 1991). Neet (1989, quoted by Brünner and Neet 1991) showed that in contact zones both species occupy the same trophic niche. However, studies on the diet of $S$. coronatus are rare. Kischnick (1984, quoted by Hausser 1990) studied the contents of 8 stomachs of $S$. coronatus from Germany. This study analyzed the diet of $S$. coronatus from the northern Iberian Peninsula. Our data were also compared with those of $S$. araneus from central Europe.

\section{Material and methods}

The diet of Sorex coronatus was studied by the analysis of 178 digestive tracts (106 males, 72 females) captured in the Quinto Real Massif (western Pyrenees, Iberian Peninsula) from September 1984 until August 1986. The area is dominated by an acidophilus Fagus sylvatica forest. Areas without arboreal vegetation are dominated by Erica cinerea and E. vagans, and bramble patches with 
a preponderance of Rubus sp. Captures took place between $660 \mathrm{~m}$ and $1000 \mathrm{~m}$ above sea level (a.s.l.). Average annual precipitation is about $2138 \mathrm{~mm}$, with the highest levels in spring and autumn. The annual average temperature is $8.8^{\circ} \mathrm{C}$. The highest average temperature is in August $\left(16.6^{\circ} \mathrm{C}\right)$ and the lowest in January $\left(2.9^{\circ} \mathrm{C}\right)$.

In order to establish a reference collection of virtual prey, monthly sampling was carried out during the year on the invertebrate community in the study area. Invertebrate samples were obtained from humus layers $\left(0.25 \mathrm{~m}^{2}\right)$ for the forest and heath-groves by Berlese funnel, from forest ground surface by means of pit-fall traps and also by colection of invertebrates from the surroundings and below forest fallen logs.

Digestive tracts were preserved in $60 \%$ alcohol, whilst awaiting analysis. The minimum numbers of consumed prey for each tract were estimated from the remains identified in the stomach and intestines. Contents of the digestive tracts were identified by use of a stereoscopical microscope at 10x and $40 \times$ magnification.

The Ruiz and Jover (1983) method was used to determine the importance and variation of the different trophic components. This develops the model defined by Pielou (1966a, b, 1975), Hurtubia and Di Castri (1973) and Hurtubia (1973). The method requires a matrix with rows representing different food types, and columns the distinct variables: appearance frequency in number $(\mathrm{N})$ and percentage $(\% \mathrm{~N})$, percentage of stomachs with a determinate type of food $(\% \mathrm{P})$ and Simpson's dominance ratio $\left(\mathrm{D}=\Sigma \mathrm{P}_{i}{ }^{2}\right)\left(1 \leq i \leq z, z\right.$-total number of digestive tracts). $\mathrm{P}_{i}$ is the probability of a food unit from stomach $i$ belonging to a certain type of food. $\mathrm{D}^{\prime}=\mathrm{D} / z \times 100$ compares the different matrix indices. $\mathrm{D}^{\prime \prime}=\mathrm{D}^{\prime} / \Sigma \mathrm{D}^{\prime} \times 100$ expresses the value of $\mathrm{D}^{\prime}$ as a percentage.

The cumulative diversity curve $\mathrm{H}_{z}$ was drawn by arranging the stomachs according to their diversity in increasing or decreasing order. This was used to estimate the representativity of the sample studied. To calculate the diversity of the diet the Brillouin expression was used: $\mathrm{H}=1 / \mathrm{N} \times$ $\left(\log N !-\log N_{i} !\right)$. This equation is better suited to this kind of data than others (Pielou 1966a, 1975, Hurtubia 1973, Ruiz 1985). The value of $\mathrm{H}_{z}$ corresponded to the last value of the cumulative diversity function. $\mathrm{H}_{p}=1 /(z-\mathrm{t}) \Sigma \mathrm{hk},(\mathrm{t}+1 \leq k \geq z) . \mathrm{hk}=\left(\mathrm{M}_{k} \times \mathrm{H}_{k}-\mathrm{M}_{k}-1 \times \mathrm{H}_{k}-1\right) /\left(\mathrm{M}_{k}-\mathrm{M}_{k}-1\right), \mathrm{M}_{k}$ - number of prey of the $k$ digestive tract, $\mathrm{H}_{k}$ - diversity of the $k$ digestive tract, $\mathrm{t}$ - point at which $\mathrm{H}_{k} / k$ curve becomes stabilized. The average diversity value $\left[\overline{\mathrm{H}}=\Sigma \mathrm{H}_{i} / z(1 \leq i \leq z)\right]$ and the equitability (E) were also compared. The similarity of diets in each season were evaluated by Spearman's correlation coefficient. The diets of both sexes were compared with the Kolmogorov-Smirnov test and Spearman's correlation coefficient.

A comparisons between field availability and diet inclusion of prey species was calculated using the similarity coefficient defined as follows $\mathrm{C}=2 w /(a+b)$ (Ryan 1986), being $w$ the sum of the lower of the two pair percentage values for each type of invertebrate, $a$ the sum of all the percentage values for invertebrates of the diet and $b$ the sum of all the percentage values for the invertebrates of the field.

\section{Results}

\section{Annual diet}

Figure 1 shows the cummulative diversity, in which tracts are ordered according to their diversity, in increasing and decreasing order. In the case of decreasing order, diversity stabilization is considered after the accumulation of the contents of 25 alimentary tracts. Therefore, it is possible to assess that the sample is representative of the species' diet. However, to calculate $\mathrm{H}_{p}$ it was considered that the definitive stabilization took place after the accumulation of 146 tracts. 
Table 1. Trophic matrix of the annual diet of Sorex coronatus $(n=178) . \mathrm{N}$ - appearance frequency in number, $\% \mathrm{~N}$ - appearance frecuency in percentage, $\% \mathrm{P}$ - percentage of stomachs with a determinate type of food, D - Simpson's dominance ratio $\left(\mathrm{D}=\Sigma \mathrm{P}_{i}{ }^{2}, \mathrm{P}_{i}\right.$ - probability of a food unit from stomach $i$ belonging to a certain type of food, $1 \leq i \leq z, z$-total number of digestive tracts), $\mathrm{D}^{\prime}=\mathrm{D} / \mathrm{z} \times 100$, $\mathrm{D}^{\prime \prime}=\mathrm{D}^{\prime} / \Sigma \mathrm{D}^{\prime} \times 100$.

\begin{tabular}{|c|c|c|c|c|c|c|}
\hline Prey type & $\mathrm{N}$ & $\% \mathrm{~N}$ & $\% \mathrm{P}$ & $\mathrm{D}$ & $\mathrm{D}^{\prime}$ & D" \\
\hline \multicolumn{7}{|l|}{ Oligochaeta } \\
\hline Plesiopora & 7 & 0.7 & 2.2 & 0.32 & 0.18 & 0.54 \\
\hline Opistopora & 113 & 11.3 & 55.0 & 7.22 & 4.06 & 12.18 \\
\hline Gastropoda & 70 & 7.0 & 38.8 & 5.15 & 2.89 & 8.68 \\
\hline \multicolumn{7}{|l|}{ Crustacea } \\
\hline Isopoda & 34 & 3.4 & 19.1 & 1.64 & 0.92 & 2.76 \\
\hline \multicolumn{7}{|l|}{ Myriapoda } \\
\hline Chilopoda & 128 & 12.8 & 60.7 & 12.70 & 7.13 & 21.41 \\
\hline Diplopoda & 26 & 2.6 & 14.0 & 1.03 & 0.58 & 1.73 \\
\hline \multicolumn{7}{|l|}{ Arachnida } \\
\hline Araneae & 36 & 3.6 & 19.7 & 1.10 & 0.62 & 1.86 \\
\hline Opiliones & 33 & 3.3 & 18.5 & 1.62 & 0.91 & 2.74 \\
\hline Pseudoscorpiones & 3 & 0.3 & 1.7 & 0.13 & 0.07 & 0.22 \\
\hline Acarina & 40 & 4.0 & 20.2 & 1.53 & 0.86 & 2.58 \\
\hline \multicolumn{7}{|l|}{ Insecta } \\
\hline Collembola & 4 & 0.4 & 2.2 & 0.12 & 0.07 & 0.21 \\
\hline Thysanura & 2 & 0.2 & 1.1 & 0.04 & 0.02 & 0.07 \\
\hline Diplura & 2 & 0.2 & 1.1 & 0.27 & 0.15 & 0.45 \\
\hline Coleoptera adult & 69 & 6.9 & 35.9 & 4.73 & 2.66 & 7.97 \\
\hline Coleoptera larvae & 57 & 5.7 & 30.9 & 2.47 & 1.39 & 4.17 \\
\hline Diptera adult & 20 & 2.0 & 11.2 & 0.95 & 0.53 & 1.60 \\
\hline Diptera larvae & 220 & 22.0 & 41.6 & 10.49 & 5.90 & 17.70 \\
\hline Lepidoptera larvae & 29 & 2.9 & 14.6 & 2.61 & 1.47 & 4.40 \\
\hline Hemiptera & 60 & 6.0 & 23.6 & 3.15 & 1.77 & 5.31 \\
\hline Orthoptera & 4 & 0.4 & 2.2 & 0.25 & 0.14 & 0.43 \\
\hline Hymenoptera & 25 & 2.5 & 4.5 & 0.65 & 0.37 & 1.10 \\
\hline Dermaptera & 3 & 0.3 & 1.7 & 0.14 & 0.08 & 0.23 \\
\hline Anoplura & 1 & 0.1 & 0.6 & 0.04 & 0.02 & 0.07 \\
\hline Siphonaptera & 5 & 0.5 & 2.8 & 0.31 & 0.17 & 0.52 \\
\hline Ephemeroptera adult & 2 & 0.2 & 1.1 & 0.13 & 0.07 & 0.22 \\
\hline Trichoptera larvae & 4 & 0.4 & 2.2 & 0.10 & 0.06 & 0.17 \\
\hline Vertebrata & 2 & 0.2 & 1.1 & 0.28 & 0.16 & 0.47 \\
\hline Plants & 1 & 0.1 & 0.6 & 0.11 & 0.06 & 0.19 \\
\hline
\end{tabular}

The analysis of the digestive tracts determined 1000 different preys items. The average number of prey items for each digestive tract was $\bar{x}=5.6(n=178, \mathrm{SE}=$ 0.325 ).

In total, 28 different types of food were determined. Diptera larvae are the most abundant prey taxa (Table 1). Chilopoda are the second in numerical importance. 
However, their presence in the digestive tracts was habitual constant, and they were considered the dominant prey in the diet according to Simpson's index. From the 128 Chilopoda detected, 99 (77.3\%) belonged to Lithobiomorpha, 28 (21.9\%) to Geofilomorpha and $1(0.8 \%)$ to Scolopendromorpha.

The Oligochaeta: Opistopora, all of them Lumbricidae, made up a high proportion of the diet. Sixty out of 113 specimens found were small species of Lumbricidae mostly Dendrobaena. The frequent presence of earthworms in the digestive tract increases the importance attributed by the Simpson's index (D") in relation to their numerical percentage.

Gastropoda were scanty in number, but they appeared in a high proportion of the tracts analyzed. They could thus be considered an important source of food according to Simpson's index. Adult Coleoptera were also a prominent food. There were 60 Hemiptera, 40 of them (66.7\%) were identified as Aphididae.

There were also Coleoptera, Acarina, Araneae, Isopoda and Opilionida larvae, all of which had lower numerical importance. Among Acarina $(n=40)$ at least 18 belonged to Oribatidae.

Fourteen percent of the total diet $(\% \mathrm{~N})$ was composed by 17 different types of food: Lepidoptera larvae, Diplopoda (4 Polidesmidae, 17 Glomeridae, 5 Julidae), adult Diptera, Hymenoptera (19 Formicidae, 3 Ichneumonidae), Siphonaptera, Oligochaeta: Plesiopora, Collembola, Orthoptera, Trichoptera larvae, Pseudoscorpionida, Dermaptera, Thysanura, Diplura, adult Ephemeroptera, Anoplura, vertebrates and plants.

In total 871 invertebrates were captured on the ground's surface by means of pit-fall traps, 742 collected from the surrounding area and under fallen trunks, and 746 from humus layer samples. Table 2 shows that almost all captured invertebrates from different samples appear in the diet of Sorex coronatus. Nevertheless, the similarity coefficient between diet and the list of invertebrates available from each habitat sampled changes considerably, being greater in comparison with humus layer samples and lower in comparison with surface samples.

Table 2. Number of invertebrate ecological types found in the diet of Sorex coronatus, number of invertebrate types collected from the different sampling mediums, percentage of invertebrate types found in the diet of collected specimens in each sampling medium and the similarity coefficient (C) between diet and samples from each medium.

\begin{tabular}{lcccc}
\hline & $\begin{array}{c}\text { Diet of } \\
\text { S. coronatus }\end{array}$ & $\begin{array}{c}\text { Ground surface } \\
\text { samples }\end{array}$ & $\begin{array}{c}\text { Forest fallen } \\
\text { trunks samples }\end{array}$ & $\begin{array}{c}\text { Humus layer } \\
\text { samples }\end{array}$ \\
\hline $\begin{array}{l}\text { Number of invertebrate types } \\
\text { Number of invertebrate }\end{array}$ & 26 & 17 & 19 & 20 \\
$\quad \begin{array}{l}\text { types found in the diet } \\
\text { Percentage }\end{array}$ & 16 & 19 & 19 \\
C & 94.1 & 100.0 & 95.0 \\
\hline
\end{tabular}


Figure 1 shows the interval of variation for Sorex coronatus trophic diversity. curves. The values obtained for each different kind of diversity are the following: $\overline{\mathrm{H}}=1.131(\mathrm{SE}=0.036, n=178) ; \mathrm{H}_{p}=3.773(\mathrm{SE}=0.203, n=31) ; \mathrm{H}_{z}=3.690$, $\mathrm{E}=0.768$.

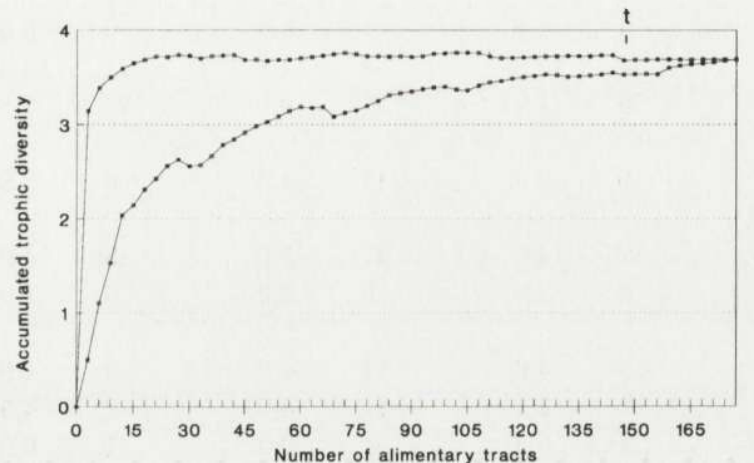

Fig. 1. Cummulative trophic diversity, arranging the digestive tracts $(n=178)$ according to their increasing (lower curve) and decreasing (upper curve) diversity order. Point $t$ represents the tract where the curve becomes stable.

\section{Seasonal variation in the diet}

Table 3 shows the shrew's diet for each season, and its diversity variation. The diet showed high correlation among seasons (Table 4). Opistopora (Lumbricidae) maintained similar values all year long: between $10.8 \%(\% \mathrm{~N})$ in spring and $13.6 \%$ in autumn. Gastropoda accounted for $8.9 \%$ during winter, decreasing progresively to $4.0 \%$ in summer and increasing again in autumn. Chilopoda were $10.7 \%$ in winter, increasing progressively and maintaining the percentage for the rest of the year between $13.6 \%$ and $14.9 \%$.

Adult Coleoptera were $3.7 \%$ in winter, $6.8 \%$ in spring, $10.3 \%$ in summer, and decreased in autumn to $5.8 \%$. Hemiptera was proportionaly low in winter $(4.1 \%)$ and spring $(1.5 \%)$, reaching $8.1 \%$ in summer and $9.7 \%$ in autumn. Coleoptera larvae kept a low but constant count during the whole year. The extreme values were $6.5 \%$ in autumn and $4.4 \%$ in summer. Diptera larvae showed high seasonal variation: in winter their count was $32.8 \%$, in spring $28.9 \%$, in summer $9.9 \%$, and in autum increasing up to $14.3 \%$.

\section{Diet comparison between sexes}

Diets of males and females were compared using the Kolmogorov-Smirnov test with a maximum distance observed $d=0.1785, p=0.99994$. Spearman's correlation coefficients were $r_{\mathrm{S}}=0.861, p<0.001, n=28$. According to this, diets in both sexes did not differ significantly. Males $(n=106)$ had a trophic spectrum made 
Table 3. Seasonal diet for Sorex coronatus. $\mathrm{N}$ - number of prey items, $\% \mathrm{~N}$ - percentage of $\mathrm{N}$ according to the total prey items.

\begin{tabular}{|c|c|c|c|c|c|c|c|c|}
\hline \multirow{2}{*}{ Prey type } & \multicolumn{2}{|c|}{ Spring } & \multicolumn{2}{|c|}{ Summer } & \multicolumn{2}{|c|}{ Autumn } & \multicolumn{2}{|c|}{ Winter } \\
\hline & $\mathrm{N}$ & $\% \mathrm{~N}$ & $\mathrm{~N}$ & $\% \mathrm{~N}$ & $\mathrm{~N}$ & $\% \mathrm{~N}$ & $\mathrm{~N}$ & $\% \mathrm{~N}$ \\
\hline \multicolumn{9}{|l|}{ Oligochaeta } \\
\hline Plesiopora & 4 & 1.2 & 1 & 0.4 & 0 & 0.0 & 0 & 0.0 \\
\hline Opistopora & 35 & 10.8 & 32 & 11.8 & 21 & 13.6 & 29 & 10.8 \\
\hline Gastropoda & 25 & 7.7 & 11 & 4.0 & 12 & 7.8 & 24 & 8.9 \\
\hline \multicolumn{9}{|l|}{ Crustacea } \\
\hline Isopoda & 9 & 2.8 & 11 & 4.0 & 6 & 3.9 & 10 & 3.7 \\
\hline \multicolumn{9}{|l|}{ Myriapoda } \\
\hline Chilopoda & 47 & 14.5 & 37 & 13.6 & 23 & 14.9 & 27 & 10.1 \\
\hline Diplopoda & 9 & 2.8 & 8 & 2.9 & 3 & 1.9 & 8 & 3.0 \\
\hline \multicolumn{9}{|l|}{ Arachnida } \\
\hline Araneae & 15 & 4.6 & 11 & 4.0 & 3 & 1.9 & 10 & 3.7 \\
\hline Opiliones & 7 & 2.1 & 11 & 4.0 & 7 & 4.5 & 10 & 3.7 \\
\hline Pseudoscorpion. & 1 & 0.3 & 0 & 0.0 & 1 & 0.6 & 1 & 0.4 \\
\hline Acarina & 12 & 3.7 & 11 & 4.0 & 5 & 3.2 & 10 & 3.7 \\
\hline \multicolumn{9}{|l|}{ Insecta } \\
\hline Collembola & 0 & 0.0 & 2 & 0.7 & 1 & 0.6 & 0 & 0.0 \\
\hline Thysanura & 0 & 0.0 & 0 & 0.0 & 2 & 1.3 & 0 & 0.0 \\
\hline Diplura & 0 & 0.0 & 2 & 0.7 & 0 & 0.0 & 0 & 0.0 \\
\hline Coleoptera adult & 22 & 6.8 & 28 & 10.3 & 9 & 5.8 & 10 & 3.7 \\
\hline Coleoptera larvae & 17 & 5.2 & 12 & 4.4 & 10 & 6.5 & 16 & 6.0 \\
\hline Diptera adult & 5 & 1.5 & 6 & 2.2 & 4 & 2.6 & 6 & 2.2 \\
\hline Diptera larvae & 94 & 28.9 & 27 & 9.9 & 22 & 14.3 & 88 & 32.8 \\
\hline Lepidoptera larvae & 10 & 3.1 & 11 & 4.0 & 5 & 3.2 & 4 & 1.5 \\
\hline Hemiptera & 5 & 1.5 & 22 & 8.1 & 15 & 9.7 & 11 & 4.1 \\
\hline Orthoptera & 0 & 0.0 & 4 & 1.5 & 0 & 0.0 & 0 & 0.0 \\
\hline Hymenoptera & 0 & 0.0 & 22 & 8.1 & 3 & 1.9 & 0 & 0.0 \\
\hline Dermaptera & 0 & 0.0 & 2 & 0.7 & 1 & 0.6 & 0 & 0.0 \\
\hline Anoplura & 1 & 0.3 & 0 & 0.0 & 0 & 0.0 & 0 & 0.0 \\
\hline Siphonaptera & 2 & 0.6 & 0 & 0.0 & 1 & 0.6 & 1 & 0.4 \\
\hline Ephemeroptera adult & 1 & 0.3 & 1 & 0.4 & 0 & 0.0 & 0 & 0.0 \\
\hline Trichoptera larvae & 3 & 0.9 & 0 & 0.0 & 0 & 0.0 & 1 & 0.4 \\
\hline Vertebrata & 0 & 0.0 & 0 & 0.0 & 0 & 0.0 & 1 & 0.4 \\
\hline Plants & 1 & 0.3 & 0 & 0.0 & 0 & 0.0 & 1 & 0.4 \\
\hline$n$ & 59 & & 50 & & 25 & & 44 & \\
\hline $\mathrm{H}_{p}$ & 3.6 & & 3.81 & & 3.49 & & 3.54 & \\
\hline $\mathrm{H}_{z}$ & $3.2 \mathrm{~s}$ & & 3.71 & & 3.47 & & 3.18 & \\
\hline $\mathrm{E}$ & $0.7 €$ & & 0.84 & & 0.82 & & 0.78 & \\
\hline
\end{tabular}

up by 27 types of food, while females ( $n=72$ ) had 22 types. The trophic diversity for each one of the sexes was as follows. Males: $\overline{\mathrm{H}}=1.111(\mathrm{SE}=0.048, n=106)$, 
Table 4. Seasonal diet comparison with the Spearman correlation test. ${ }^{* *}$ - correlation coefficient value significant for $p<0.001$.

\begin{tabular}{lccc}
\hline Season & Spring & Summer & Autumn \\
\hline Winter & $0.909^{* *}$ & $0.720^{* *}$ & $0.869^{* *}$ \\
Spring & & $0.711^{* *}$ & $0.801^{* *}$ \\
Summer & & & $0.868^{* *}$ \\
\hline
\end{tabular}

$\mathrm{H}_{p}=3.780(\mathrm{SE}=0.234, n=109), \mathrm{H}_{z}=3.597, \mathrm{E}=0.755$. Females: $\overline{\mathrm{H}}=1.160(\mathrm{SE}$ $=0.056, n=72), \mathrm{H}_{p}=3.762(\mathrm{SE}=0.087, n=45), \mathrm{H}_{z}=3.624, \mathrm{E}=0.815$.

\section{Discussion}

Kischnick (1984, quoted by Hausser 1990) analyzed 8 Sorex coronatus stomach contents from Bonn (Germany), from November to March. He found that numerically the most important prey items were Coleoptera and Diptera larvae, Hemiptera, Araneae, adult Coleoptera and Isopoda. Comparing our results (appearance frequency) with those of Kischnick (1984) for autumn and winter, there was a high correlation between both diets $\left(r_{\mathrm{S}}=0.768, \mathrm{df}=22, p<0.001\right)$.

Hausser and Meylan (1984) noted that $S$. coronatus had the same ecological niche as $S$. araneus. Nevertheless, the first species was less adapted to a severe climate. Neet (1989, quoted by Brünner and Neet 1991) considered that in the contact zone, both species occupied the same trophic niche.

Rudge (1968) also found that in Great Britain (Scotland, Wytham Woods and Exeter) the main part of $S$. araneus prey items included Lumbricidae, Mollusca, Hemiptera, Diptera, Coleoptera, Lepidoptera and plants. When our data are compared with those of Rudge (1968) (appearance frequency, except for non identified diets) there was no correlation with the Scottish area $\left(r_{\mathrm{S}}=0.200, \mathrm{df}=22, p>0.1\right)$, but a significant correlation in the Wytham Woods $\left(r_{\mathrm{S}}=0.358, \mathrm{df}=26, p<0.05\right)$ and Exeter $\left(r_{\mathrm{S}}=0.383, \mathrm{df}=27, p<0.05\right)$.

Kischnick (1984, quoted by Hausser 1990) described a $S$. araneus diet around Bonn, from November to March essentially based on Gastropoda, Araneae, Isopoda, Hemiptera, Coleoptera larvae and Diptera larvae. Comparing these results with ours (appearance frequency), we found a high correlation between the two species $\left(r_{\mathrm{S}}=0.822, \mathrm{df}=22, p<0.001\right)$.

When our data from $S$. coronatus are compared with different populations of S. araneus (Rudge 1968, Pernetta 1976, Butterfield et al. 1981, Churchfield 1982, 1984, Kischnick 1.c.), both species appear to have similar diets. Different types of prey are common to both species: Lumbricidae, adult Coleoptera, Gastropoda, Coleoptera larvae, Hemiptera and in some cases Diptera larvae. The most remarkable feature of the Quinto Real population of $S$. coronatus was the high occurrence of Chilopoda in its diet. This must depend on the characteristics of the 
study area (Castién 1994). Neet (1989, quoted by Brünner and Neet 1991) indicated that both species occupy a similar trophic niche in the contact zone.

$S$. araneus diet is based mainly on animals that live in the humus layer. This could be related to a subterranean way of life (Pernetta 1976, Butterfield et al. 1981), as revealed under laboratory conditions (Ellenbroek 1990).

Diet similarities for $S$. coronatus and $S$. araneus also suggested a similar way of life. $S$. coronatus feeds on almost all available resources (Table 2) which shows a clear tendency towards a trophic oportunism. Differences between the diet and the invertebrates from different sampling areas indicate a high level of correlation between feedings habits and humus faunistic composition, while the correlation between the diet and the ground's surface fauna is very low. The former corroborates the opinion that this species uses subterranean galeries for the majority of its feeding activity.

Comparison between $\mathrm{H}_{p}$ and $\mathrm{H}_{z}$ for the whole sampling indicated a similarity in both values. This verified the absence of intra-populational diet patterns. The high value of $\mathrm{H}_{z}$ implied a diversified diet. Meanwhile, the high equitability value showed an equal feeding distribution between used resources.

Concerning the seasonal diversity values, $\mathrm{H}_{p}$ was higher than $\mathrm{H}_{z}$ in winter and spring. It was related to certain intra-populational trophic segregation within the sample in this period. In summer and autumn the food sources diversified and the values of $\mathrm{H}_{p}$ and $\mathrm{H}_{z}$ were closer. This suggested the lack of different trophic patterns in the population during these periods.

Males ingested more types of food, but the females diet had a higher equitability ratio. The diversity value was not different between sexes. Consequently, a trophic differentiation between sexes could not be concluded.

Acknowledgements: The authors thank I. Leránoz (Pamplona) for his collaboration in the sampling and P. J. Abbott for corrections of English.

\section{References}

Bever K. 1983. Zur Nahrung der Hausspitzmaus, Crocidura russula (Hermann, 1780). Säugetierkundliche Mitteilungen 31: 13-26.

Brünner H. and Neet C. R. 1991. A parapatric scenery: the distribution and ecology of Sorex araneus and Sorex coronatus (Insectivora, Soricidae) in southwestern Germany. Zeitschrift für Säugetierkunde 56: 1-9.

Butterfield J., Coulson J. C. and Wanless S. 1981. Studies on the distribution, food, breeding biology and relative abundance of the pygmy and common shrews (Sorex minutus and $S$. araneus) in upland areas of northern England. Journal of Zoology, London 195: 169-180.

Castién E. 1994. Estudio bioecológico de los micromamíferos (Insectivora y Rodentia) de un hayedo acidófilo. Quinto Real. Navarra. Tesis Doctoral. Universidad de Barcelona, Barcelona: 1-668.

Catzeflis F., Graf J., Hausser J. and Vogel P. 1982. Comparaison biochimique des Musaraignes de genre Sorex en Europe occidentale (Soricidae, Mammalia). Zeitschrift für Zoology, Systematics und Evolution 20: 223-233.

Churchfield S. 1982. Food availability and the diet of the common shrew, Sorex araneus in Britain. Journal of Animal Ecology 51: 15-28. 
Churchfield S. 1984. Dietary separation in three species of shrew inhabiting water-cress beds. Journal of Zoology, London 204: 211-228.

Ellenbroek F. J. M. 1990. An experimental analysis of interspecific competition in the shrews Sorex araneus L. and S. minutus L. (Soricidae, Insectivora). Meijendel Comité, New Series. 113: 5-123.

Handwerk J. 1987. Neue Daten zur Morphologie, Verbreitung und Ökologie der Spitzmäuse Sorex araneus und Sorex coronatus im Rheinland. Bonner zoologische Beiträge 38: 273-297.

Hausser J. 1984. Genetic drift and selection: their respective weights in the morphological and genetic differentiation of four species of shrews in Southern Europe (Insectivora, Soricidae). Zeitschrift für Zoology, Systematics und Evolution 22: 302-320.

Hausser J. 1990. Sorex coronatus Millet, 1882. Schabrackenspitzmaus. [In: Handbuch der Säugetiere Europas. Band 3/1. J. Niethammer and F. Krapp, eds]. Aula-Verlag, Wiesbaden: 279-286.

Hausser J., Catzeflis F., Meylan A. and Vogel P. 1985. Speciation in the Sorex araneus complex (Mammalia: Insectivora). Acta Zoologica Fennica 170: 125-130.

Hausser J. and Meylan A. 1984. La Musaraigne couronnée. Sorex coronatus. [In: Atlas des mammiferes sauvages de France. Page 32. Societé française pour l'etude et la protection des mammiferes eds]. Societé française pour l'etude et la protection des mammiferes. Paris: 1-299.

Hurtubia J. 1973. Trophic diversity measurement in sympatric predatory species. Ecology 54: $885-890$.

Hurtubia J. and Di Castri F. 1973. Segregation of lizard faunas of the chaparral communities in Chile and California. [In: Mediterranean type ecosystems. Origin and structure. F. Di Castri and H. A. Mooney, eds]. Ecological Studies VII, Springer-Verlag, New York: 349-363.

Meylan A. 1964. Le polymorphisme chromosomique de Sorex araneus L. (Mammalia, Insectivora). Revue suisse de Zoologie 71: 903-983.

Meylan A. and Hausser J. 1978. Le type chromosomique A des Sorex du groupe araneus: Sorex coronatus Millet, 1828 (Mammalëa, Insectivora). Mammalia 42: 115-122.

Neet C. R. and Hausser J. 1990. Habitat selection in zones of parapatric contact between the common shrew Sorex araneus and Millet's shrew S. coronatus. Journal of Animal Ecology 59: 235-250.

Pernetta J. C. 1976. Diets of the shrews Sorex araneus L. and Sorex minutus L. in Wytham grassland. Journal of Animal Ecology 45: 8919-913.

Pielou E. C. 1966a. Species-diversitty and pattern-diversity in the study of ecological succession. Journal of Theoretical Biology 10): 370-383.

Pielou E. C. 1966b. The measurement of diversity in different types of biological collections. Journal of Theoretical Biology 13: 131-14:4.

Pielou E. C. (ed) 1975. Ecological Diversity. John Wiley and Sons, New York: 1-165.

Rudge M. R. 1968. The food of the common shrew Sorex araneus L. (Insectivora: Soricidae) in Britain. Journal of Animal Ecology 37: 56i5-581.

Ruiz X. 1985. An analysis of the diet of Cattle Egrets in the Ebro Delta, Spain. Ardea 73: 49-60.

Ruiz X. and Jover L. 1983. Tipificación trófica de poblaciones mediante estimas de la dominancia y de la diversidad. Actas XV Congreso Internacional Fauna Cinegética y Silvestre, Trujillo: 695-707.

Ryan J. M. 1986. Dietary overlap in sympatric populations of pigmy shrews, Sorex hoyi, and masked shrews Sorex cinereus, in Michigan. Canadian Field-Naturalist 100: 225-228.

Received 26 September 1994, accepted 25 February 1995. 